\title{
Modernisasi dan Perubahan Sosial Masyarakat Desa Lala Kabupaten Buru
}

\author{
M. Rusdi ${ }^{1}$, Radi Udin Alfian Sangaji ${ }^{2}$, Lutfi Rumkel ${ }^{3}$, Munawwarah Emba $^{4}$, Ismail ${ }^{5}$ \\ ${ }^{1}$ Pendidikan Sosiologi, Universitas Iqra Buru \\ ${ }^{2}$ Pendidikan Agama Islam, Universitas Iqra Buru \\ ${ }^{3}$ Ilmu Hukum, Universitas Iqra Buru \\ ${ }^{4}$ Bahasa Ingris, Sekolah Tinggi DDI Pangkep \\ ${ }^{5}$ Pendidikan Sosiologi, Sekolah Tinggi DDI Pangkep \\ Email: $\frac{{ }^{\text {rusdigallarang92@ gmail.com }}{ }^{2}{ }^{\text {radiudinalfiansangaji@gmail.com }}{ }^{3} \text { lutfirumke19@ gmail.com }}{{ }_{\text {gillyowend@yahoo.com }}^{5}{ }^{5} \text { ismailsosiologi2@gmail.com }}$
}

\begin{abstract}
This study aims to describe the effect of modernization on social change as well as the inhibiting and supporting factors. The next goal is to reveal and explain the positive values contained in modernization and social change. This research is a descriptive qualitative research. Informants are determined by purposive sampling. Data collection is done by; observation, interview, and documentation. As well as data analysis is carried out in stages; data reduction, data presentation and data verification. The results of the study explain that the effect of modernization on social change is; scientific thinking and lifestyle changes. At first the people in meeting their daily needs, they took advantage of the natural surroundings. However, with the entry of modernization they began to follow the lifestyle that characterizes modern society. Several factors supporting the occurrence of modernization and social change, namely; heterogeneous society, dissatisfaction in various fields of life, and the perspective of humans who must improve their standard of living. While the inhibiting factors are; attitudes that are still traditional, the emergence of fear of shakiness of integration, and bad prejudice against elements of foreign culture.
\end{abstract}

Keywords: Modernization, Community Social Change.

\begin{abstract}
Abstrak
Penelitian ini bertujuan untuk mendeskriptifkan pengaruh modernisasi terhadap perubahan sosial serta faktor penghambat dan pendukungnya. Tujuan selanjutnya, yaitu untuk mengungkap dan menjelaskan nilai-nilai positif yang terkandung dari modenisasi dan perubahan sosial. Penelitian ini adalah jenis penelitian kualitatif yang bersifat deskriptif. Informan ditentukan secara Purposive Sampling. Pengumpulan data dilakukan dengan cara; observasi, wawancara, dan dokumentasi. Serta analisis data dilakukan dengan tahapan; reduksi data, penyajian data dan verifikasi data. Hasil penelitian menjelaskan bahwa pengaruh modernisasi terhadap perubahan sosial, yaitu; berpikir ilmiah, dan perubahan gaya hidup. Pada awalnya masyarakat dalam memenuhi kebutuhan sehari-hari, mereka memanfaatkan alam sekitar. Namun, dengan masuknya modernisasi mereka mulai mengikuti gaya hidup yang mengcirikan masyarakat modern. Beberapa faktor pendukung terjadinya modernisasi dan perubahan sosial, yaitu; masyarakat yang heterogen, ketidakpuasan di berbagai bidang kehidupan, dan cara pandang mengenai manusia yang harus memperbaiki taraf hidupnya. Sedangkan faktor penghambat, yaitu; sikap yang masih tradisional, munculnya ketakutan akan terjadinya kegoyahan integrasi, dan prasangka buruk terhadap unsur budaya asing.
\end{abstract}

Kata Kunci: Modernisasi, Perubahan Sosial Masyarakat.

\section{PENDAHULUAN}

Modernisasi merupakan bagian dari perubahan sosial yang mengcakup transformasi dari kehidupan tradisional atau pramodern. Wujud dari modernisasi ialah adanya perkembangan aspek kehidupan modern, diantaranya mekanisme media massa yang teratur, urbanisasi maupun peningkatan pendapatan perkapita. Perubahan struktural yang berhubungan dengan lembaga-lembaga sosial, norma dan stratifikasi sosial adalah bagian dari proses modernisasi. Artinya proses modernisasi mengcakup semua aspek yang berhubungan dengan kehidupan manusia. Beberapa perubahan yang terjadi pada masyarakat Desa Lala terjadi dalam dua aspek, yaitu;

Pertama, aspek pola pikir. Masyarakat memiliki pola pikir yang terhitung masih terbelakang, beberapa orang tua siswa yang baru tamat SMA enggan untuk melanjutkan pendidikan anaknya sampai ke jenjang perguruan tinggi. Pola pikir semacam ini muncul karena banyaknya para alumni 
perguruang tinggi yang selesai strata satu kembali menjadi petani dan nelayang di Desa. Sedangkan di masa sekarang pola pikir demikian sudah berubah. Kedua, dimensi Kultural. Setiap individu di lingkungan masyarakat pada dasarnya mengikuti budaya yang diwariskan oleh nenek moyangnya. Namun sekarang, beberapa budaya yang telah diwariskan telah dimodifikasi dan tergantikan dengan budaya lain. Interaksi dilakukan dengan cara bertemu langsung. Namun, dengan perkembangan teknologi komunikasi model interaksi dengan cara bertemu langsung sudah tergantikan dengan menggunakan alat komunikasi handhpone dan sejenisnya. Dengan adanya beberapa alat komunikasi yang tidak mengenal jarak, menyebabkan masyarakat jarang bertatap muka secara langsung.

Berdasarkan realitas tersebut, memberikan gambaran tentang suatu perubahan dapat meberikan dampak positif dalam kehidupan manusia. Namun, jika suatu perubahan bergerak tidak sesuai dengan fungsinya. Maka, sebaliknya ia akan memberikan dampak negatif. Setiap manusia pada dasarnya akan terus mengalami perubahan karena keinginan dan kepentingan mereka yang tidak terbatas.

Sehingga masalah yang diteliti adalah bagaimana pengaruh modernisasi terhadap perubahan sosial masyarakat serta faktor penghambat dan pendukung terjadinya perubahan tersebut. Penelitian ini bertujuan untuk mendeskriptifkan pengaruh modernisasi terhadap perubahan sosial dan faktor penghambat dan pendukungnya. Tujuan selanjutnya dari penelitian ini adalah untuk mengungkap dan menjelaskan nilai-nilai positif yang terkandung dari modenisasi dan perubahan sosial yang terjadi di Desa Lala Kabupaten Buru.

Selanjutnya, pada penelitian ini state of the art, diambil contoh penelitian terdahulu sebagai panduan diantaranya adalah jurnal Kalimah Nasional dan Jurnal Ekonomi Pertanian dan Agribisnis Nasional. Dapat dilihat pada gambar yang telah dilampirkan.
Tabel 2.1 State Of The Art

\begin{tabular}{|l|l|}
\hline Judul Penelitian & $\begin{array}{l}\text { Dampak Modernisasi Terhadap Perubahan Sosial Masyarakat Tani di } \\
\text { Desa Kambata Tana Kabupaten Sumba Timur }\end{array}$ \\
\hline Peneliti & Diana Andayani Djoh \\
\hline tahun & 2018 \\
\hline Variabel yang terkait & Modernisasi Terhadap Perubahan Sosial \\
\hline Hasil/ Temuan & $\begin{array}{l}\text { Hasil penelitian menunjukkan bahwa ada perubahan yang terjadi } \\
\text { pada pola pikir dan perilaku masyarakat desa Kambata Tana di satu } \\
\text { sisi menerima kehadiran modernisasi dalam bidang pertanian, namun } \\
\text { di lain sisi mereka masih tetap memegang teguh nilai-nilai budaya } \\
\text { dan kearifan lokal yang dianut. Transformasi pertanian yang terjadi } \\
\text { hanya sebatas pada cara produksi tanpa merubah struktur sosial } \\
\text { masyarakat. Modernisasi pertanian membawa dampak pada } \\
\text { berkurangnya kebutuhan tenaga kerja. Tenaga kerja manusia dan } \\
\text { hewan dapat digantikan oleh mesin-mesin modern seperti traktor, } \\
\text { pompa air, mesin pengering jagung dan padi. }\end{array}$ \\
\hline Persamaan & $\begin{array}{l}\text { Penelitian ini sama-sama meneliti tentang Modernisasi dan Perubahn } \\
\text { Sosial. }\end{array}$ \\
\hline Perbedaan & $\begin{array}{l}\text { Penelitian yang dilakukan olch Diana Andayani Djoh adalah dampak } \\
\text { modernisasi terhadap perubahan sosial masyarakat, yang berlokasi di } \\
\text { Desa Kambata Tana Kabupaten Sumba Timur. Sedangkan penelitian } \\
\text { ini meneliti tentang modernisasi dan perubahan sosial masyarakat } \\
\text { dan rencana di lakukan di Desa Lala, Kabupaten Buru. }\end{array}$ \\
\hline
\end{tabular}

Berikut merupakan tabel State Of the art kedua yang terlihat jelas perbedaan dalam metode penelitiaannya.

Tabel 2.2 State Of The Art

\begin{tabular}{|l|l|}
\hline Judul Penelitian & Modernisasi dan Perubahan Sosial dalam Lintasan Sejarah Islam \\
\hline Peneliti & Syamsul Bakri \\
\hline tahun & 2016 \\
\hline Variabel yang terkait & Modernisasi dan Perubahan Sosial \\
\hline Hasil/ Temuan & $\begin{array}{l}\text { Hasil penelitian ini menunjukkan, bahwa Modernisasi merupakan } \\
\text { keharusan kosmik yang tak terelakkan, sehingga dunia Islam dipaksa } \\
\text { oleh sejarah untuk dapat memberikan tanggapan sekaligus } \\
\text { beradaptasi dengan dinamika modernitas yang terjadi. Sebagai } \\
\text { dampak nyata, proses ini melahirkan para intelektual aktivis berbasis } \\
\text { Islam, yakni para intelektual Muslim yang berkecimpung dalam aksi- } \\
\text { aksi pergerakan sosial. Mereka berusaha menjawab tantangan zaman } \\
\text { dengan segala kemodernannya. Islam hadir di tengah umat yang } \\
\text { membutuhkan jawaban atas modernitas yang semakin hari semakin } \\
\text { menjadi }\end{array}$ \\
\hline Persamaan & $\begin{array}{l}\text { Penelitian ini sama-sama meneliti tentang Modernisasi dan } \\
\text { Perubahan Sosial }\end{array}$ \\
\hline Perbedaan & $\begin{array}{l}\text { Penelitian yang dilakukan oleh Syamsul Bakri adalah modernisasi } \\
\text { dan perubahan sosial dalam Lintasan Sejarah Islam. Sedangkan } \\
\text { penelitian ini meneliti tentang modernisasi dan perubahan sosial yang } \\
\text { terjadi di Desa Lala, Kabupaten Buru. }\end{array}$ \\
\hline
\end{tabular}

\section{METODE}

Penelitian ini adalah jenis penelitian deskriptif kualitatif yaitu peneliti memberikan gambaran secara sistematis dan jelas terkait dengan objek yang diteliti. Maksud dari penelitian ini didasari untuk menggambarkan secara deskriptif mengenai pengaruh modernisasi terhadap perubahan sosial masyarakat serta faktor penghambat dan pendukung terjadinya perubahan sosial masyarakat di Desa Lala Kabupaten Buru. Penelitian ini dilakukan di Desa Lala Kabupaten Buru.

Informan ditentukan secara Purposive Sampling dimana pemilihan informan dipilih berdasarkan ketentuan bahwa informan tersebut adalah yang melakukan, mengalami, mengetahui dan memahami persis masalah yang diteliti. Informan adalah masyarakat lokal yang 
sudah lama tinggal menetap di Desa Lala, dengan kriteria sampel benar-benar sesuai dengan penelitian yang akan dilakukan. Informan dalam penelitian ini adalah masyarakat lokal yang mempunyai pengaruh dan berkompeten dalam wilayah tersebut seperti tokoh masyarakat, tokoh adat, tokoh agama, kepala Desa, dan kepala Kecamatan.

Teknik pengumpulan data dilakukan dengan tahapan: Pertama observasi, data yang diperoleh melalui observasi meliputi pengaruh modernisasi terhadap perubahan sosial masyarakat serta faktor penghambat dan pendukung terjadinya perubahan sosial. Kedua wawancara, data yang didapatkan melalui proses wawancara adalah informasi tentang pengaruh modernisasi terhadap masyarakat Desa Lala serta faktor penghambat dan pendukungnya sehingga terjadi perubahan sosial. Dalam proses ini, peneliti akan menjelaskan maksud dan tujuan peneliti yang dilakukan kepada informan secara terpisah antara informan satu dengan informan lainnya. Membangun suasana kekeluargaan dengan informan, dan mengajukan butir-butir pertanyaan sesuai fokus penelitian. Teknik wawancara akan dibantu dengan teknik rekam dan catat untuk memperoleh dat primer dari informan dan didukung oleh data sekunder yang diperoleh dari hasil observasi, catatan lapangan, pengkajian bahan pustaka berupa buku-buku, jurnal, artikel, pemberitaan media cetak atau internet, maupun foto-foto yang relenvan dengan fokus penelitian. Ketiga, Dokumentasi. Adapun data yang didapatkan melalui dokumentasi ini adalah data-data tentang tempat penelitian seperti jumlah penduduk, luas wilayah, keadaan lingkungan, data tentang pengaruh modernisasi dan perubahan sosial, serta faktor penghambat dan pendukungnya.

Sedangkan, analisis data dilakukan dengan cara; reduksi data, penyajian data dan verifikasi data. Dari proses verifikasi peneliti mencoba untuk menemukan makna dari data yang telah terkumpul. Kemudian dari data yang telah terkumpul maka akan ditarik kesimpulan.

\section{HASIL DAN PEMBAHASAN}

\section{A. Modernisasi dan Perubahan Sosial}

Proses modernisasi telah merambah ke segala bidang dalam kehidupan manusia, mulai dalam bentuk modenisasi teknologi (materi) sampai pada tingkat ide. Berbagai wujud dari modernisasi bermunculan dalam kehidupan manusia, banyak yang tidak disadari dan dapat dikatakan hampir semua manusia berada pada arus modernisasi.

Beberapa sifat modernisasi yang mengcakup berbagai aspek dalam kehidupan masyarakat, sehingga masyarakat pedesaan juga tidak bisa menghindar dan ikut arus dalam proses modernisasi. Masyarakat Desa Lala merupakan suatu wilayah yang terletak di Kabupaten Buru, yang berada cukup jauh dari kota Ambon sebagai ibu kota provinsi. Namun, masyarakat Desa Lala juga telah mengalami proses modernisasi. Unsur-unsur budaya dan sistem sosial lama, dahulunya masih diikuti oleh masyarakat Desa Lala. Namun seiring berputarnya waktu, masyarakat secara berlahanlahan beralih ke unsur budaya dan sistem sosial baru.

Pada dasarnya modernisasi bersifat relatif, ia bergantung terhadap dimensi ruang dan waktu. Dimensi ruang bergantung terhadap masyarakat yang melakukan modernisasi. Begitupun pada dimensi waktu dalam modernisasi memiliki sifat yang relatif. Sesuatu yang dianggap modern saat ini, kemungkinan akan dianggap masih tradisional di masa yang akan datang.

Proses modernisasi yang terjadi di Desa Lala, berawal dari kedatangan masyarakat luar dari berbagai daerah yang membawa unsur budaya dan sistem sosial yang berbeda dengan penduduk asli. Dengan adanya perbedaan unsur budaya memicu munculnya pertentangan antara pendatang dengan penduduk asli. Realitas tersebut menjadi suatu kewajaran bagi penduduk asli, karena mereka belum terbiasa melakukan penyusaian dengan hal-hal baru yang berasal dari luar. Namun, mereka yang termasuk penduduk asli tidak menjadikan hal tersebut sebagai masalah yang bersifat berkelanjutan, dalam artian masyarakat menerima perubahan. 
Beberapa pengaruh modernisasi terhadap perubahan sosial masyarakat di Desa Lala, yaitu: Pertama, berpikir ilmiah. Masyarakat mulai berpikir ilmiah terhadap segala sesuatu maupun dalam bertindak, terutama di pada bidang pendidikan dan pengajaran. Di masa lalu, masyarakat menyampingkan jenjang pendidikan di perguruan tinggi, karena menggagap hal tersebut hanya menguras harta benda. Sehingga jenjang pendidikan generasi mereka hanya sampai pada tingkat SMP dan SMA. Padahal dengan melanjutkan pendidikan sampai ke jenjang perguruan tinggi, mampu mengubah kehidupan dari berbagai aspek. Karena ilmu yang mereka dapat, bisa diterapkan di berbagai kegiatan yang ada di masyarakat sesuai dengan disiplin ilmu yang dimilikinya.

Kedua, perubahan gaya hidup. Beberapa gaya hidup mulai berubah, pada awalnya mereka memenuhi kebutuhan hidup dengan memanfaatkan alam sekitar. Namun, dengan masuknya modernisasi masyarakat mulai mengikuti gaya hidup yang ada di kota khususnya pada kalangan remaja, mulai dari model rambut, bahasa, cara berpakaian, model rumah maupun selera makanan, yang semuanya itu mencirikan masyarakat modern. Masyarakat Desa Lala pada awalnya memiliki model rumah dan ukuran sederhana yang mengcirikan masyarakat Buru dan memanfaatkan kayu dari hutan. Namun seiring dengan perkembangan zaman, bahan-bahan tersebut dimodifikasi dengan menggunakan bahan-bahan dari beton dan sejenisnya. Cara berpakaian juga telah mengikuti trend masyarakat kota.

Pengaruh modernisasi mengubah masyarakat Desa Lala menjadi masyarakat yang memiliki cara hidup konsumtif yang dimana, cara hidup tersebut menggunakan banyak pengeluaran dan tidak sesuai dengan mata pencaharian mereka sebagai nelayan. Walaupun hal tersebut termasuk sesuatu yang baik. Namun, apabila gaya hidup seperti itu tidak berbanding lurus dengan ekonomi. Maka perilaku konsumtif yang demikian akan memunculkan masalah baru di kemudian hari, yang malah memperparah ekonomi masyarakat itu sendiri.

\section{B. Faktor Pendukung dan penghambat terjadinya Perubahan Sosial}

Setiap perubahan sosial yang terjadi, selalu diawali oleh beberapa faktor yang menjadi pendukung dan penghambat. Beberapa faktor pendukung terjadinya perubahan sosial di Desa Lala, yaitu;

Pertama, masyarakat yang heterogen atau terdiri dari beraneka ragam suku, yaitu; makassar, bugis, padang dan jawa. Dengan adanya latar belakang perbedaan budaya menyebabkan perbedaan persepsi antar kelompok. Perbedaan tersebut menjadi pendorong terjadinya perubahan, masyarakat yang memiliki latar belakang budaya yang berbeda, akan lebih muda mengalami pertentangan karena adanya pertemuan unsur yang berbeda. Sehingga, beberapa masyarakat selalu dituntut untuk melakukan kompromi antar anggota. Hal ini yang kemudian menjadi pendorong terjadinya perubahan sosial.

Kedua, ketidakpuasan di berbagai bidang kehidupan. Dengan adanya ketidakpuasan di berbagai bidang menjadi pendorong terjadinya perubahan sosial, khususnya pada bidang ekonomi. Misalnya; jika suatu individu memiliki barang baru, dan pada saat yang sama individu lain mengetahuinya. Maka individu yang lain juga berusaha untuk memiliki barang yang sama. Hal ini menunjukan, bahwa suatu individu tidak mau ketinggalan dengan individu lain. Sehingga, hampir semua masyarakat memiliki jenis barang yang sama mulai dari peralatan rumah, bentuk rumah, dll.

Ketiga, cara pandang mengenai manusia yang harus berusaha memperbaiki taraf hidupnya. Cara pandang seperti ini akan memberikan perubahan terhadap individunya. Karena dengan cara pandang yang demikian, maka masyarakat akan terbuka dengan hal-hal baru yang bisa menopang kebutuhan dan mempermuda aktivitasnya.

Sedangkan, faktor penghambat terjadinya perubahan sosial, yaitu; Pertama, sikap yang masih tradisional. Masyarakat pada umumnya sangat mengagungkan kebiasaan-kebiasaan lama, sehingga mereka enggang untuk melakukan perubahan. Kedua, munculnya ketakutan akan terjadinya kegoyahan integrasi. Pada umumnya Integrasi adalah harapan dan 
cita-cita masyaraka, karenanya integrasi adalah sesuatu yang dilindungi oleh masyarakat. Sehingga beberapa hal-hal yang dianggap baru ditolak, untuk menghindari kegoyahan.

Ketiga, prasangka buruk terhadap unsur budaya asing. Sikah seperti demikian adalah sesuatu yang wajar dan sering dijumpai pada masyarakat yang terjajah oleh bangsa asing. Beberapa pengalaman-pengalaman terdahulu menjadi faktor munculnya prasangka buruk terhadap beberapa budaya asing.

Masyarakat Desa Lala termasuk tipologi Desa Swadaya. Karena Desa ini memiliki kondisi yang masih relatif statis tradisional. Sehingga kehidupan masyarakatnya tergantung pada kemampuan dan keterampilan pimpinannya. Stratifikasi masyarakatnya masih bersifat vertikal serta statis. Kedudukan seseorang di lingkungan masyarakat dinilai sesuai keturunan dan luasnya kepemilikan lahan tanah.

\section{KESIMPULAN}

Pengaruh modernisasi terhadap perubahan sosial di Desa Lala, yaitu; Pertama, berpikir ilmiah. Masyarakat mulai berpikir ilmiah terhadap segala sesuatu yang terjadi di lingkungannya maupun terhadap informasi yang mereka peroleh. Hal ini mempengaruhi cara mereka bertindak, terutama di bidang pendidikan dan pengajaran. Kedua, perubahan gaya hidup. Pada awalnya masyarakat Desa Lala dalam memenuhi kebutuhan sehari-hari, mereka memanfaatkan alam sekitar. Namun, dengan masuknya modernisasi masyarakat sekarang mulai mengikuti gaya hidup di kota khusunya di kalangan remaja, mulai pada selera makanan, cara berpakaian, model rumah, serta gaya hidup konsumtif yang semuanya mengcirikan masyarakat modern.

Perubahan sosial terjadi karena dipengaruhi oleh beberapa faktor pendukung dan penghambat, faktor pendukungnya yaitu; masyarakat yang heterogen, ketidakpuasan di berbagai bidang kehidupan, dan cara pandang mengenai manusia yang harus berusaha memperbaiki taraf hidupnya. Sedangkan faktor penghambatnya, yaitu; sikap yang masih tradisional, munculnya ketakutan akan terjadinya kegoyahan integrasi, dan prasangka buruk terhadap unsur budaya asing.

\section{SARAN}

Peneliti masih perlu melakukan penelitian terkait tentang fokus masalah yang diangkat pada penelitian ini tentang pengaruh modernisasi terhadap perubahan sosial masyarakat faktor yang menjadi penghambat dan pendukung terjadinya perubahan tersebut. Hal ini, berguna untuk melakukan perbandingan serta mengkaji masyarakat mengenai modernisasi dan perubahan sosial di lingkungan masyarakat.

\section{UCAPAN TERIMA KASIH}

Ucapan terima kasih kepada Allah SWT, yang telah memberikan peneliti kesehatan dalam menyelesaikan penelitian ini. Serta ucapan terima kasih kepada pihak Direktorat Riset dan Pengabdian Masyarakat Direktorat Jenderal Riset dan Pengembangan Kementerian Riset, Teknologi, dan Pendidikan Tinggi (RISTEKDIKTI) yang telah memberikan bantuan dana.

\section{DAFTAR PUSTAKA}

Adon Nasrullah Jamaludin. (2016). Sosiologi Pembangunan. Bandung: Pustaka Setia, h. 42.

Azra, A. (2019). Pendidikan Islam: tradisi dan modernisasi di tengah tantangan milenium III. Prenada Media.

Cahyono, A. S. (2016). Pengaruh media sosial terhadap perubahan sosial masyarakat di Indonesia. Jurnal Publiciana, 9(1), 140-157.

Martono, N. (2012). Sosiologi perubahan sosial: Perspektif klasik, modern, posmodern, dan poskolonial (sampel halaman). Raja Grafindo Persada Jakarta.

Muin Idianto. 2006. Sosiologi Jilid 3. Jakarta:Erlangga.

Nuraini, N., Riadi, A., Umanailo, M. C. B., Rusdi, M., Badu, T. K., Suryani, S., ... \& Hentihu, V. R. (2019). Political Policy for the development of Education. Int. J. Sci. Technol. Res, 8(10). 
Ritzer, George. (2014). Teori Sosiologi Modern. Jakarta: Prenadamedia Group.

RUSDI, M., \& RUSDI, M. (2017). Dinamika Sosial Masyarakat Di Sekiat Bukit Karampuang Desa Barugae Kecamatan Bulukumpa Kabupaten Bulukumba (Doctoral dissertation, Doctoral dissertation, Pascasarjana).

Rusdi, M., Papuangan, A. A., Ismail, I., Mardiah, R., \& Arifuddin, A. (2020). PROBLEM SOSIAL ANAK PUTUS SEKOLAH (STUDI KASUS DI DESA LALA KABUPATEN BURU). Jurnal CONTEMPLATE, 1(02).

Rusdi, M., Wabula, A. L., Goa, I., \& Ismail, I. (2020). Solidaritas Sosial Masyarakat Petani Di Desa Wanareja Kabupaten Buru. Jurnal Ilmiah Mandala Education, 6(2).

Saptono.(2006). "Sosiologi.". Phibeta: Jakarta. Hal. 72

Soerjono Soekanto. (1990). "Sosiologi Suatu Pengantar". Rajawali Pers: Jakarta.

Wabula, A. L., Umanailo, M. C. B., Kurniawan, R., Rusdi, M., \& Nuthihar, R. (2019). GERAKAN BUPOLO MAGHRIB MENGAJI SEBAGAI MEDIA PRURALISME. JISPO: Jurnal Ilmu Sosial dan Ilmu Politik, 9(2), 1-18. 